\title{
The impact of COVID-19 epidemic on development of micro, small and medium enterprises policy in East Kalimantan government
}

\author{
Finnah Fourqoniah; Muhammad Fikry Aransyah*
}

Faculty of Social Science and Political Science, Mulawarman University, Indonesia

*To whom correspondence should be addressed. Email: fikryaransyah@fisip.unmul.ac.id

\begin{tabular}{|l|l|l|l|l|}
\hline DOI: & Received: & Revised: & Accepted: & Published: \\
$10.22437 /$ ppd.v9i2.10805 & 27.10 .2020 & 24.06 .2021 & 26.06 .2021 & 30.06 .2021 \\
\hline
\end{tabular}

\begin{abstract}
This article discusses the efforts of the East Kalimantan Government handling cases of development of micro, small, and medium enterprises (MSMEs) during the COVID-19. The handling strategy can be assessed by understanding the measures, steps, and policies formulated and implemented by the East Kalimantan government. A deliberative policy analysis approach was used to analyze this case. This approach analyzes the narratives and arguments of the authorities to understand decision-making and policy implementation. The writing of this article uses a qualitative approach by utilizing the descriptive analysis method. The data collection technique used is a literature study using books, journal articles, newspapers, online news, and traditional institutions' websites. First, this paper's essential findings are reallocation and refocusing of the Covid-19 Budget for the cost of economic stimulus to strengthen capital for affected businesses and small industry players. Second, relaxation and credit restructuring. Third, the temporary closure policy for cafes or restaurants is due to residents' ignorance or non-compliance with government calls regarding health protocols. As a result, efforts to deal with it have stalled because the wider community does not support it. Combining these three factors complicates the provincial government's efforts to deal with MSMEs' development during the COVID-19 pandemic in East Kalimantan. Policy recommendations for the recovery of MSMEs in East Kalimantan Province, namely increasing the role of Indagkop through fostering and educating MSMEs in utilizing technology to sell online and the one-door policy for MSMEs.
\end{abstract}

Keywords: COVID-19, East Kalimantan, MSME, Policy analysis

JEL Classification: I38, O25, R58

\section{INTRODUCTION}

Since January 2020, Corona Virus Disease-IV (COVID-19) has infected more than 2,245,872 worldwide (WHO, 2020). More than 152,000 people have been confirmed to have died from this virus (WHO, 2020). Therefore, it would not be brave if government leaders in many countries struggled to get out of the COVID-19 outbreak with their approaches. In China, for example, the government has responded to the Covid-19 outbreak by providing outstanding health facilities for coronavirus patients. China's government turned sports halls, schools, and hotels into temporary hospitals, 
conducting rapid-test or Polymerase Chain Reaction (PCR) on many residents to lock down the city (Aida, 2020).

Currently, Micro, Small, and Medium Enterprises (MSMEs) face significant problems due to Covid-19. According to Lu, Wu, Peng, and Lu (2020), most SMEs in China were unable to resume operations due to a lack of epidemic mitigation supplies, the incapacity of personnel to return to work, interrupted supply chains, and diminished market demand. Many SMEs were also encountering cash flow issues because they had to continue paying for different fixed expenses despite having little or no revenue. These problems include decreased sales, capital problems, delays in distributing products and raw materials. The crisis has also incurred unprecedented global health and economic costs of action to tackle the spread of Covid-19, particularly the lockdown, to the detriment of global economic activity. MSMEs are one of the most vulnerable and hit markets. There is a consensus that not all SMEs worldwide can survive Covid-19 (Syriopoulos, 2020).

As the backbone of the national economy, MSMEs dominate in terms of gross output value and trade value, and the number of unemployed in this pandemic. According to data from the Ministry of Cooperatives and Small and Medium Enterprises (KemenkopUKM), Indonesia had 64,194,057 MSMEs (around 99\% of the total business sector) in 2018, employing 116,978,631 workers (around 97\% of the total workforce). In facing the Corona COVID-19 pandemic, MSMEs need to be continuously strengthened. Here, the provincial government's role plays a role in formulating policies to survive small and medium enterprises.

The development of MSMEs in East Kalimantan Province increases every year, such as in 2018, totaling 211,548 units. Then it increased to 302,527 units in the position of October 2019. For MSME data in 2019, 302,527 units consisted of 89,798 culinary units, 13,921 management industries, and 1,573 craft units. Then for trade activities covering 168,795 units, service sector 28,440 units (Kaltimprov, 2019). The increase in the number of SMEs every year is indeed inseparable from the policy's role in handling the Provincial Government through the East Kalimantan Department of Industry, Trade, Cooperatives, Small and Medium Enterprises (Indagkop). Particularly in cooperatives and MSMEs that continue to provide guidance and assistance with tools and assistance, the legality of micro and small business licenses, and distribution of KUR (People's Business Credit) funds are channeled to assist SMEs in business development through banks in East Kalimantan. Indagkop also provides guidance and disseminates various policies, such as business clinics and websites. With these two program policies, it can help business actors how to distribute the resulting production. Likewise, all information is available at business clinics or opening websites to increase business capital.

The explanation above is a policy in handling MSMEs in 2019; new policies need to be implemented in 2020. The new policies that have been implemented during 2020 will be analyzed through deliberative policy analysis, a method that can be used to discuss the role of argument, rhetoric, and narratives in the policy analysis process (Fischer, 2007). Deliberative policy analysis can be interpreted to analyze policy through a complex combined structure of policy arguments between interpretations, opinions, evaluation, and facts. The core of this approach places ideas as policy material in a specific institutional or situational setting. The Marsh \& Smith (2000) approach was utilized by combining it with the implementation approach of Edward III in Agustino (2020) to analyze the implementation of policies for handling the COVID-19 outbreak.

Meanwhile, there is still minimal discussion regarding COVID-19 in Indonesia, especially in the context of policy. Therefore, this paper seeks to fill this gap. Although 
there are still few studies and articles on COVID-19, they are still there, and the description focuses more on the health context, among which are written by Susilo et al. (2020) and Yuliana (2020). Both of them discussed COVID-19 from the side of the health literature. Apart from that, Mas'udi \& Winanti (2020) also elaborated on social and political studies and in other contexts, such as local governments (Dzakwan. 2020) and food policy (Hirawan \& Verselita, 2020). However, the description of this article is different from the writings mentioned above. The difference lies in the policy narrative conveyed through budget relocation from the local government, relaxation and credit restructuring, and citizens' indifference to government calls resulting in the Temporary Closing Policy for Cafe or Restaurant. In order to develop arguments to explain the above assumptions, this article focuses on the deliberative policy analysis method for analyzing policy and how its implementation impacts handling the COVID-19 outbreak in the development of MSMEs in East Kalimantan.

\section{METHODS}

This article uses a qualitative approach with a descriptive analysis method. The qualitative approach was chosen because of its ability to gain a deep, authentic, and basic understanding of the observed phenomenon. The descriptive analysis method is used because the data and information collected focus on actual phenomena or problems through data collection, preparation, processing, and concluding. The results of all attempts to describe an objective empirical state of the phenomenon or problem being studied. While the data collection technique used is the literature study and was done because of the limitations in directly interviewing authoritative sources at the time of writing.

The COVID-19 outbreak and the implementation of large-scale social restrictions (PSBB) in several cities have limited space for movement, so that direct in terviews are not possible. The qualitative method of using in-depth interviews was combined with observation, online focus group discussions with informants and policymakers. The informants were the SME community from Mini University Kaltim Preneurs and policymakers are from the Department of Industry, Trade, Cooperatives, and SMEs (Indakop). The literature study referred to in the context of this article is an attempt to find, collect. The study was written material in books, journal articles, online and conventional news, and websites of institutions (such as who. int, Kaltimprov.go.id, covid 19. go. id) relating to the phenomena and problems studied. Finally, the data analysis technique in writing this article departs from Creswell and Poth's (2016) explanation, which focuses on organizing data, reading and monitoring, and describing, clarifying, and interpreting data into codes and themes.

\section{RESULTS AND DISCUSSION}

\section{Reallocation and refocusing of the COVID-19 Budget on COVID-19 pandemic}

Reallocation and refocusing of the Covid-19 Budget on the Covid-19 pandemic, which requires the government's extraordinary policies, will undoubtedly impact the State Budget (APBN) and Regional Revenue and Expenditure Budget (APBD) in 2020. Investors' concerns over Covid -19 also influenced the occurrence of capital outflow in Indonesia. The 2020 State Budget will also face tax revenue, non-tax state revenue, and customs due to economic actors' conditions and falling commodity prices (Suparman, 2021). This pandemic has an impact on state revenue that has fallen by $10 \%$. However, at the same time, state spending must increase health and social assistance and help business actors not carry out massive layoffs and caused the deficit to widen by $5 \%$ (Junaidi, Sukarna, Arifin, \& Soegianto, 2020). 
The minister of finance's statement (kemenkeu.go.id, 2020) estimates that income will decrease by $10 \%$, expenditure increases to support the health sector by IDR 75 trillion, social safety net IDR 110 trillion. Expenditures were high for public protection. The estimated deficit was from 1.76\% of GDP or IDR307.2 trillion to 5.07\% or IDR853 trillion, but it was attempted to be below 5\%. As the changes in the impact of Covid-19 are increasingly widespread, joint efforts are needed between the government and local governments through reallocation and refocusing of the 2020 APBN and APBD to handle the pandemic impact of Covid-19 (Sudaryanto, 2020).

For this reason, the Provincial Government of East Kalimantan needs to make adjustments to the 2020 budget year according to the guidelines set out in the Joint Decree of the Minister of Home Affairs and the Minister of Finance Number 119/2813 / SJ and 117 / KMK.07 / 2020 concerning Acceleration of 2020 APBD Adjustments. In the Context of Handling Covid-19 and Safeguarding Public Purchasing Power and the National Economic and Regulation of the Minister of Finance Number 35 / PMK.07 / 2020 concerning Transfers to Regions and Village Funds for FY 2020. The APBD adjustment results are outlined in the APBD Adjustment Report and, after that, must be submitted to the Ministry of Finance and the Ministry of Home Affairs. To ensure the local government's commitment to preventing/handling Covid-19, according to PMK No.35 / PMK.07 / 2020 above, local governments that do not meet the provisions of the 2020 APBD Report can postpone the distribution of part of the General Allocation Fund (DAU) and Profit-Sharing Fund (DBH).

There are seven priority points for activities carried out by the Provincial Government of East Kalimantan through the budget refocusing of the 2020 budget. This policy was conveyed by the Governor of East Kalimantan at the Hearing Meeting (RDP) for East Kalimantan's Efforts to Face the Spread of Covid-19 in East Kalimantan with the East Kalimantan Regional People's Representative Assembly (DPRD), Monday, April 6, 2020. At the 29th East Kalimantan, DPRD Plenary Meeting approved the 2020 East Kalimantan Provincial P-APBD as a whole was reduced by Rp1.45 trillion so that the original APBD was Rp12.29 trillion to Rp.10.83 trillion.

In the second phase of $\mathrm{Rp} 351,612$ billion, the total refocusing is seven points for using the budget: the procurement of personal protective equipment (PPE) for medical personnel, vitamins, rapid tests, and medical equipment (medical equipment). They were providing incentives for health workers according to the guidelines given by the Minister of Health. Repair of health facilities and infrastructure and buildings for people/patients under supervision. Besides, transportation/accommodation and consumption (quality nutrition) for medical personnel include providing convenience and appreciation (appreciation) to medical personnel and their residence. Next, the cost of handling the economic impact is assistance funds to people who have social risks coordinated by the East Kalimantan Provincial Social Service. People affected by Covid 19 will pay attention to the East Kalimantan provincial government. This regional budgeting is still being improved by coordinating with district and city governments. Furthermore, the cost of economic stimulus is capital strengthening for affected MSMEs and small industry players through the Department of Industry, Trade, Cooperatives, Small and Medium Enterprises East Kalimantan (Kaltimprov.go.id, 2020).

The East Kalimantan Indagkop has implemented several work programs with a budget given by the East Kalimantan provincial government, facilitating online cheap markets, food production, clothing, and new entrepreneurial guidance Presidential Assistance for Small Micro Enterprises (BPUM). BPUM intended for capital assistance for micro-business actors for the Acceleration of the State Economy (PEN). Following the direction of the President regarding the acceptance of the Productive Social 
Assistance Program for Micro Enterprises starting on August 17, 2020, to December 31, 2020, the East Kalimantan Provincial Government is conducting data coordination and verification of the Presidential Assistance Program for Micro and Small Businesses (BPUM). The Ministry of Cooperatives and Small and Medium Enterprises targets 12 million Micro Business Actors who do not receive working capital credit and investment in banking to become additional capital for micro-business actors. This solution will help their businesses can continue to run amid the pandemic and reduce poverty and unemployment. As of September 9, 2020, the number of Micro Enterprises proposed is 41,390 Micro Enterprises in East Kalimantan. With the largest number from Penajam Paser Utara, 10,278 Micro Enterprises (Indagkop.Kaltimprov.go.id, 2020).

The reality in the field is that the budget refocusing policy is still focused on the social impact management program and the cost of health care out of a total of seven priority activity points. Permendagri 20 mandates economic recovery. This priority has not been discussed in depth by the executive regarding economic recovery. The economic recovery program is mandated by the Minister of Home Affairs Regulation (Permendagri) Number 20 of 2020 to the government in each region to accelerate the handling of the impact of the Covid-19 pandemic, which is not only allocated such as incentives for MSME players or exemption from local tax fees. However, it also ensures that an area's economic growth can return to normal, especially in the MSME and other informal sectors.

Primarily problems with the supply of goods to the commodities market and logistics sector in regions during the Covid-19 pandemic (Shafi, Liu, \& Ren, 2020). The desired goal is to push the wheels of this economy to run as before the Covid-19 pandemic. Because what is affected is not only MSMEs but almost all economic lines. If this sector wants to be supported, the provincial Government through Indagkop needs to make a capital stimulus. For example, the exemption of market levies on traders for three months was enforced in Balikpapan. If they are released until December, it is part of the economic recovery so that their income is not burdened with paying levies to the government. In general, the programs carried out by the government are already in the right corridor, and it is essential to evaluate their implementation in the field.

\section{Credit relaxation and restructuring}

Apart from budget reallocation and refocusing problems, credit relaxation and restructuring have also become problems in developing MSMEs in Indonesia. Especially in East Kalimantan, the concession to pay installments for one year refers to the restructuring period stipulated in the Regulation of the Financial Services Authority (POJK) Stimulus. The installment concession is intended more for small debtors, including the informal sector, micro-businesses, daily income workers who must pay credit to run their productive business. Informal work refers to workers who have a particular type of homeownership bill or simple housing program. Food stall entrepreneurs are forced to close because there is a policy of implementing Work From Home (WFH).

Relaxation of this arrangement will be enforced for up to one year after stipulation but can be extended if needed. Through Press Release Number 14 / DHMS / OJK / $3 / 2020$, OJK asked banks to transmit the stimulus that the government has submitted immediately. This stimulus is expected to provide space for the real sector to continue running its business in this challenging time. Loosening the statutory reserve requirement set by Bank Indonesia can provide much liquidity to the banking sector. Lower interest rates can be transmitted in pricing for cheaper lending rates.

Besides, the policy of providing economic stimulus with the issuance of POJK No.11 / POJK.03 / 2020 concerning National Economic Stimulus as a Countercyclical 
Policy for the Impact of the Spread of Coronavirus Disease 2019. This stimulus is valid from March 13, 2020, to March 31, 2021, and hopes that banks will be proactive in identifying debtors who have been affected by Covid-19, including MSME debtors, still observe the principle of prudence along with a monitoring mechanism.

The East Kalimantan Provincial Government asks banks or non-bank financing companies following the Financial Services Authority Regulation (POJK), which provides relief to debtors and customers to come to banks or non-bank financing offices to receive explanations of relief. Banks and non-bank companies must provide the provision of relief. This policy also reduces the burden on people now hit by the coronavirus or Covid-19 outbreak, as for sanctions or reprimands to support the people's welfare. Local governments do not do this to banks or non-bank institutions if they heed the President's policies.

From OJK East Kalimantan's (2020) data for September 2020, the number of MSMEs potentially affected by COVID-19 reached 100,834 debtors. With the realization of credit restructuring totaling 38,733 accounts. Of this amount, the outstanding value is Rp. 2.47 trillion. The debtor business sector of the economy that is most affected is wholesale and retail trade. Namely, 85,504 accounts with a debit balance of Rp. 6.79 trillion. "Of the debtors affected by COVID-19, 38,111 accounts (44.83\%) had submitted with a debit balance of Rp. 3.17 trillion. Of those who proposed relaxation, 29,829 accounts $(77.81 \%)$ were approved with total balances-a debit of Rp 2.77 trillion. Meanwhile, 662 accounts (1.73\%) were rejected with a debit balance of Rp 53.07 billion of the debtors who had applied. Furthermore, the rest is in the bank analysis process.

Limited business activities amid the Covid-19 pandemic have increased the risk of bad credit. This risk is reflected in Non-Performing Loans (NPL) in the second quarter of 2020, at the level of 4.59 percent, higher than the first quarter of 2020, recorded at 3.46 percent. Based on its use, the increase in credit risk was due to an increase in the NPL of working capital loans from 6.69 percent in the first quarter to 8.06 percent in the second quarter. Meanwhile, the NPL of investment and consumption credit was maintained at 2.24 percent and 3.96 percent, respectively, despite increasing from 1.01 percent and 3.68 percent in the previous quarter.

Meanwhile, spatially, most districts and cities in East Kalimantan experienced an increase in NPL except for West Kutai, Mahakam Ulu, and Bontang. Like previous quarters, Balikpapan and Samarinda had the highest credit risk in the second quarter, with NPLs of 7.90 percent and 6.23 percent, increasing from 5.48 percent and respectively. 4.91 percent. If viewed per city, Samarinda and Balikpapan have a greater credit risk because these regions also have a more massive credit distribution. The credit growth of East Kalimantan in the second quarter of 2020 was recorded at 8.18 percent (YoY), lower than the previous quarter of 18.40 percent (YoY)

The existence of micro, small, and medium enterprises (MSME) is essential for economic growth. MSMEs are very important because they can absorb labor. Encouraging economic growth that contributes $61 \%$ of GDP has a diversity of sectors, encourages exports, and provides innovation. Of the 64.2 million UMKM units in Indonesia, that 97 percent absorbed the workforce. The trend of MSME funding during the pandemic, MSMEs, depends more on the informal funding sector to survive. Access to formal financial services was relatively limited. Also, during this period, there was a change in community mobility. So that in the new standard era, digital development is needed by MSMEs.

The provincial government needs to develop MSMEs through institutional strengthening (corporatization), strengthening human resources and business (capacity expansion), and strengthening access to finance so that MSMEs can become UMKM 
4.0 as the new strength of the national economy. Strengthening the corporatization of MSMEs must also be done to maintain business continuity through strengthening institutions and expanding digital market access. The local government needs to emphasize support for MSMEs in the new average era by expanding market access and improving business processes, especially in collaboration, building local heroes' culture, increasing human resource capacity, and expanding segmentation.

\section{Citizens' indifference to a government appeal}

Another problem that has caused East Kalimantan to be less successful in developing entrepreneurship in the COVID-19 pandemic is citizens' indifference to government calls regarding health protocols resulting in the Temporary Closing Policy for Cafes or Restaurants. This problem is evident because people still gather in coffee shops, cafes, malls, or places that the government has banned. From the start, the government has given residents directions to carry out physical or social distancing to keep their distance from other people. Due to the spread of the coronavirus, one of which is through saliva splashes. If people do not keep their distance, and it is known that the person being spoken to is infected or a carrier of the virus, this can infect other people and spread again to other parties. Therefore, physical or social distancing is one way out to prevent the spread of COVID-19. The government's directive is only when most people are still cooperating at the terminal, market, and others. Residents seem not worried about the virus because they are more concerned with their daily activities.

As with physical or social distancing, the government's appeal to use masks is often violated by the wider community. The residents also did not follow the invitation to wash their hands after leaving the house. Why does this happen? Based on observation, at least three possibilities are why the people are ignorant of the government's direction.

Firstly, the citizens' ignorance of the dangers of COVID-19. This ignorance is due to weak socialization carried out by the government, including local governments and their staff. The Indonesian government is not optimally socializing the need to live clean and healthy, including using masks and washing hands frequently. Several mediums can be a conduit for the spread of the coronavirus. For example, the study by van Doremalem et al. (2020) explained that the coronavirus could survive in a matter of hours to days on different mediums. The coronavirus can survive several hours in the air, last 4 to 8 hours in copper medium, last 24 hours in cardboard medium, and last up to 3 days in plastic or stainless-steel medium (van Doremalem et al., 2020). This virus resistance must be anticipated by living a clean and healthy life. The information obtained by these residents did not come from government socialization but from the community's independent efforts to find out. As a result of this ignorance, people are indifferent to the government's appeal because they do not deeply understand the deadly dangers of COVID-19.

Second, there is an interest in making ends meet, causing some residents to ignore physical or social distancing orders. This neglect was even evident during the implementation of Large-Scale Social Restrictions (PSBB) in several regions. PSBB is a policy of the Central Government (in collaboration with local governments) to overcome the COVID-19 pandemic by limiting certain activities in an area suspected of being infected. The prohibition covers teaching and learning activities (both at school and campus), religious activities, wedding receptions, concerts, tours, and public and private transportation.

Third, the absence of strict sanctions keeps human migration high; and social distancing policies are less impactful. For example, the Citra Niaga area and the Mahakam Edge area will be temporarily closed. The closure of the two places was because they were deemed not to apply the Covid-19 protocol. Hundreds of people 
hanging out at the two locations did not keep their distance, and many did not wear masks. Several times the Covid-19 Task Force found visitors and business owners who did not comply with health protocols and violated Perwali number 43 of 2020 concerning the Application of Discipline and Law Enforcement of the Covid-19 Control Health Protocol. Many visitors do not wear masks and sit close to each other for a long time. Thus, closing steps were taken so that business owners in the two locations were more orderly in implementing protocols such as adjusting the distance between table chairs, wearing masks, and a plastic barrier for cashiers. However, if this is not followed during the closing period, the closing period will be extended. The community and business actors have not followed this control because of the absence of strict sanctions.

The Governor of East Kalimantan has issued a circular containing an appeal not to gather in crowds. People are also expected to remain at home, except in specific and urgent circumstances, to leave the house. Following up on the governor's circular letter, the East Kalimantan Provincial Civil Service Police Unit (Satpol PP) and the City of Samarinda continue to disseminate information to the community. Especially in places that are usually used as gathering places. Among other things, a playground, an internet cafe, to a restaurant or cafe. The goal is to reduce interaction and even direct contact that triggers the easy spread of Covid-19. Not only food stalls, but Satpol PP also conducted outreach to internet cafes that were still open.

However, the spread of Covid-19 still occurred in East Kalimantan and was ranked 3rd in the highest distribution figures. Through the Task Force, the local government also has to work extra hard to socialize and educate the public about the importance of implementing health protocols in their daily lives (Karim, Aini, \& Akbar, 2021). There is no exception to curbing night entertainment venues (THM), which are open until 00.00 WIB or midnight. Asked to close, it turned out that THM was free to open, and even many did not use health protocols. This control is needed to justice for small business actors looking for sustenance until the night. Because of that, THM control must be done at any time. Controlling the use of masks or implementing health protocols must be carried out, including the opening and closing hours of THM and food stalls to small cafes.

The non-compliance discussed in this subsection confirms the survey of Hadi et al. (2020). Their survey found that $92.6 \%$ of respondents actively interacted in traditional markets; 84 1\% do not use masks, and $89.3 \%$ do not apply social distancing. Meanwhile, supermarkets or minimarkets are not much different. Of the $97.6 \%$ of residents active in supermarkets or minimarkets, $49 \%$ do not wear masks, and $61.7 \%$ do not heed the provincial government's instructions to carry out social distancing. Besides, this survey also found that as many as $81.7 \%$ of respondents continued to go to mosques, churches, and temples; and $72.5 \%$ of respondents are still actively hanging out or gathering in cafes and coffee shops.

Apart from that, the provincial government will no longer only echo appeal but also be firmer than implemented so far. The government must have the courage to impose punitive sanctions on citizens who do not comply with the government's appeal or direction. These sanctions deter people and make people agree to do things that the government prohibits. Besides, the sanctions given are blunt upward and apply to all people of East Kalimantan.

\section{CONCLUSIONS AND RECOMMENDATIONS}

\section{Conclusion}

Corona Virus Disease-IV (COVID-19) is a world pandemic whose spread is very massive and affects the development of MSMEs as a whole. This article analyzes the efforts made by the Government of East Kalimantan in dealing with and controlling the 
spread of COVID-19. In order to obtain data and information, the authors make use of literature study data collection. The findings obtained from the author's analysis are that the policy for handling the COVID-19 outbreak in the development of MSME in East Kalimantan is not running optimally. This problem occurs due to three essential things: reallocating and refocusing the Covid-19 Budget for economic stimulus costs to business actors and small industry players is still focused on the limited social impact management program and health care costs. Credit relaxation and restructuring due to limited business activities amid the corona pandemic (Covid-19) increases the risk of bad credit. Residents' indifference to government benefits is the third factor that results in not optimal handling of COVID-19 in East Kalimantan. The reluctance of residents to use masks, the crowds of people gathering in houses of worship, coffee shops, restaurants, and places prohibited by the government is an obstacle to social distancing. Besides, the policy that was expected to be a solution also caused most East Kalimantan people to depend on daily work in the informal economy. Many residents did not obey the government's direction.

\section{Recommendation}

Currently, MSMEs in East Kalimantan are facing significant problems as a result of Covid-19. These problems include decreased sales, capital problems, delays in distributing products and raw materials. Potential problems in the implementation of provincial government policies for MSMEs can be mapped into three categories: 1) The effectiveness of the MSME stimulus policy regarding the policy's adequacy in responding to the needs of MSMEs during a pandemic; 2) Targeting, namely the risk of exclusion or inclusion of errors, validation of recipient data, and eligibility validation; 3) Supervision related to policy implementation stages, the potential for abuse of distribution, and complaints.

Several policy recommendations for the recovery of MSMEs in East Kalimantan Province, namely increasing the role of Indagkop through fostering and educating MSMEs in utilizing technology to sell online and the one-door policy for MSMEs. The quasi-fiscal policy will then cooperate with Regional Owned Enterprises and Regional Development Banks to absorb UMKM products and establish business cooperation, and a single database system and additional data verification by field surveys.

\section{REFERENCES}

Agustino, L. (2020). Analisis Kebijakan Penanganan Wabah Covid-19: Pengalaman Indonesia. Jurnal Borneo Administrator, $16 \quad$ (2), 253-270. https://doi.org/https://doi.org/10.24258/jba.v16i2.685.

Agustino, L. (2020). Dasar-Dasar Kebijakan Publik. Bandung: Alfabeta.

Aida, R. (2020). Rekap Perkembangan Virus Corona Wuhan dari Waktu ke Waktu. Retrieved from https://www.kompas.com/tren/read/2020/01/28/054600665/rekapperkembangan-virus-corona-wuhan-dari-waktu-ke-waktu

Creswell, J. W., \& Poth, C. N. (2016). Qualitative inquiry and research design: Choosing among five approaches. Sage publications.

Dzakwan, M.H.A. (2020). Memetakan Kesiapan Pemerintah Daerah dalam Menangani COVID-19. CSIS Commentaries, April, 1-11.

Fischer, F. (2007). Deliberative policy analysis as practical reason: Integrating empirical and normative arguments. Public Administration And Public Policy-New York-, $125,223$.

Hadi, N, Kukuh SW, Nurita, D., \& Puspitasari. MA (2020). Pelanggaran Sebabkan Penularan Covid di Jawa Timur Tinggi. Retrieved from 
https://koran.tempo.co/read/nasional/454643/pelanggaran-sebabkan-penularancovid-di-jawa-timur-tinggi.

Hirawan, F.B., \& Verselita, A.A. (2020). Kebijakan pangan di masa pandemi COVID19. CSIS Commentaries DMRU-048-ID, 14.

Junaidi, M., Sukarna, K., Arifin, Z., \& Soegianto, S. (2020) Kebijakan Refocusing Anggaran Belanja Daerah dalam Penanganan Pandemi COVID-19. Halu Oleo Law Review, 4(2), 145-156.

Karim, I., Aini, I.N., \& Akbar, M.F. (2021). Coronavirus Diseases -19: an overview in education, agriculture, and communication perspectives. Jurnal Perspektif Pembiayaan Dan Pembangunan Daerah, 9(1), 73-84. https://doi.org/10.22437/ppd.v9i1.10819.

Lu, Y., Wu, J., Peng, J., \& Lu, L. (2020). The perceived impact of the Covid-19 epidemic: evidence from a sample of 4807 SMEs in Sichuan Province, China. Environmental Hazards, 19(4), 323-340.

Marsh, D., \& Smith, M. (2000). Understanding policy networks: towards a dialectical approach. Political Studies, 48(1), 4-21.

Mas'udi, W., \& Winanti, P. S. (2020). Tata Kelola Penanganan COVID-19 di Indonesia: Kajian Awal. Yogyakarta; Gadjah Mada University Press.

Shafi, M., Liu, J., \& Ren, W. (2020). Impact of COVID-19 pandemic on micro, small, and medium-sized Enterprises operating in Pakistan. Research in Globalization, 2, 100018.

Sudaryanto, E. (2020). Strategi Realokasi dan refocusing APBD Untuk Penanggulangan Pamdemi Covid-19 Studi Kasus Pada Pemerintah Daerah " $X$ ". In Seminar Nasional Manajemen, Ekonomi, Akuntansi.

Suparman, N. (2021). Strategic priorities and accountability for allocating the state budget amid Covid-19 pandemic in Indonesia. Jurnal Perspektif Pembiayaan Dan Pembangunan Daerah, 9(1), 61 - 72. https://doi.org/10.22437/ppd.v9i1.11640.

Susilo, A., Rumende. C.M.. Pitoyo, C.W., Santoso, W.D., Yulianti, M., Sinto, R., Singh, G., Nainggolan. L.. Nelwan. E.J., Khie. L.. Widhani. A.. Wijaya. E., Wicaksana. B.. Maksum. M.. Annisa. F.. Jasirwan. C.O.M., \& Yunihastuti, E. (2020). Coronavirus Disease 2019: Tinjauan Literatur Terkini. Jurnal Penyakit Dalam Indonesia, 7(1), 45-67.

Syriopoulos, K. (2020). The Impact of Covid-19 on Entrepreneurship and SMEs. Journal of the International Academy for Case Studies, 26(2), 1-2.

Van Doremalen, N., Bushmaker, T., Morris, DH, Holbrook, MG, Gamble, A., Williamson, BN, Tamin, A., Harcourt, JL, Thornburg, NJ, Gerber, SI, LloydSmith, JO, De Wit, E., \& Munster, VJ (2020). Aerosol and surface stability of SARS-CoV-2 as compared with SARS-CoV-1. New England Journal of Medicine. The New England Journal of Medicine, 382 (16), 1564-1567.

World Health Organization (WHO), 2020. Coronavirus disease (COVID-19) Pandemic. Available at: https://www.who.int/emergencies/diseases/novel-coronavirus-2019.

Yuliana, Y. (2020). Corona virus diseases (Covid-19): Sebuah tinjauan literatur. Wellness and Healthy Magazine, 2(1), 187-192.

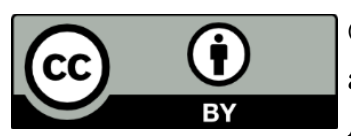

(C) 2021 by the authors. Licensee JPPD, Indonesia. This article is an open-access article distributed under the terms and conditions of the Creative Commons Attribution (CC BY) license (http://creativecommons.org/licenses/by/4.0/). 